\title{
Efek Beberapa Jenis Biochar pada Berbagai Takaran terhadap Pertumbuhan dan Hasil Tanaman Kunyit (Curcuma Domestica Val.)
}

\author{
Adrianus Simau ${ }^{\mathrm{a}}$ \\ ${ }^{a}$ Fakultas Pertanian, Universitas Timor, Kefamenanu, TTU - NTT, Indonesia, email: adrysimau94@gmail.com
}

\section{Article Info}

\section{Article history:}

Received 27 November 2020

Received in revised form 10 Januari 202 Accepted 19 Januari 2019

DOI:

https://doi.org/10.32938/sc.v6i01.1228

\section{Keywords:}

Curcuma domestica $\mathrm{Val}$

Biochar sekam Padi

Biochar batang Kirinyuh

Tanah entisol

\begin{abstract}
Abstrak
Penelitian ini bertujuan mengetahui pengaruh beberapa jenis biochar pada berbagai takaran terhadap pertumbuhan dan hasil tanaman kunyit di tanah entisol semiarid. Pelitian ini telah dilaksanakan pada bulan Januari sampai bulan Juli di kebun percobaan Fakultas Pertanian, Universitas Timor Kelurahan Sasi, Kecamatan Kota Kefamenanu, Kabupaten TTU. Metode penelitian yang digunakan menggunakan metode eksperimen dilapangan dengan Rancangan Acak Kelompok (RAK) pola faktor tunggal. Faktor 1 jenis biochar jenis biochar dengan kontrol, biochar sekam padi $5 \mathrm{t} / \mathrm{ha}$, biochar sekam padi $10 \mathrm{t} / \mathrm{ha}$, biochar sek am padi $20 \mathrm{t} / \mathrm{ha}$, biochar kerinyuh $5 \mathrm{t} / \mathrm{ha}$, biochar kerinyuh $10 \mathrm{t} / \mathrm{ha}$, dan biochar kerinyuh $20 \mathrm{t} / \mathrm{ha}$. semua perlakuan diulang 5 kali sehingga terdapat 35 unit penelitian. Hasil penelitian menunjukkan bahwa perlakuan biochar sekam padi $10 \mathrm{t} / \mathrm{Ha}$ dan $20 \mathrm{t} / \mathrm{Ha}$ berpengaruh nyata dan memberikan nilai tertinggi tehadap parameter pertumbuhan yang meliputi panjang daun, jumlah daun serta parameter lingkungan yaitu berat volume tanah. Perlakuan biochar batang kerinyuh 20 t/Ha memberikan nilai tertinggi terhadap parameter lingkungan derajat keasaman tanah dan berbeda nyata, sedangkan pada parameter daya hantar listrik, kadar lengas tanah tidak berbeda nyata. Pada parameter pertumbuhan biochar batang kerinyu dengan takaran 10 dan 20 t/Ha memberikan nilai tertinggi terhadap parameter tinggi tanaman dan diameter batang. Selanjutnya pada parameter hasil perlakuan biochar batang kerinyuh 5 t/Ha memberikan nilai tertinggi pada parameter pembentukan mata tunas rimpang, berat segar brangkasan, dan berat segar rimpang, berat kering simplisia. Sedangkan pada parameter berat kering tajuk dan indeks panen perlakuan biochar batang kerinyuh $20 \mathrm{t} / \mathrm{Ha}$ memberikan nilai tertinggi.
\end{abstract}

\section{Pendahuluan}

Kunyit (Curcuma domestica Val.) merupakan salah satu tanaman obat potensial, selain sebagai bahan baku obat juga dipakai sebagai bumbu dapur dan zat pewarna alami. Rimpangnya sangat bermamfaat sebagai antikoagulan, menurunkan tekanan darah, obat cacing, obat asma, penambah darah, mengobati sakit perut, penyakit hati, karminatif, stimulant, gatal-gatal, gigitan serangga, diare, rematik. Kandungan utama didalam rimpangannya terdiri dari minyak atsiri, kukurmin, resin, oleoresin, desmetoksikurkumin, dan bidesmetoksikurkumin, damar, gom, lemak, protein, kalsium, fosfor dan besi. zat warna kuning (kurukumin) dimamfaatkan sebagai pewarna untuk makanan manusia dan ternak Rahardjo dan Rostiana (2005). Berdasarkan data BPS produksi kunyit di kabupaten TTU masih sangat kurang oleh sebab itu perlu dilakukannya peningkatan produksi kunyit di TTU yang pada umumnya memiliki jenis tanah entisol. Tanah entisol banyak dijumpai di daerah-daerah berlahan kering salah satunya adalah Kabupaten TTU khususnya lahan Universitas timor. Tanah di sekitar kampus Univertas Timor, Kefamenanu, TTU, NTT, diklasifikasikan sebagai tanah litosol atau Entisol (Soil Survey Staff, 2014), yang solum tanahnya sangat tipis (lithic), kandungan bahan organik sangat rendah, kapasitas tukar kation sangat rendah, kapasitas retensi air dan hara sangat terbatas Berek et al, (2017).

Entisol merupakan salah satu jenis tanah mineral yang baru berkembang, yang mana sifat-sifatnya sebagian besar ditentukan oleh bahan induknya. Pada umumnya tanah Entisols-Brebes bertekstur liat, memunyai nilai reaksi tanah sangat beragam mulai dari agak asam sampai alkalis ( $\mathrm{pH} 5,6-8,5)$, mengandung hara $\mathrm{P}$ dan $\mathrm{K}$, serta kapasitas tukar kation dan kejenuhan basa tergolong tinggi. Masalah utama tanah Entisols adalah kadar bahan organik dan $\mathrm{N}$-total tergolong sangat rendah (Sumarni et al., 2012a). Sehingga perbaikan status bahan organik harus menjadi prioritas dalam pemulihan lahan terdegradasi. Peningkatan kadar bahan organik tanah juga merupakan opsi untuk penanggulangan faktor pembatas lahan kering suboptimal. Upaya perbaikan kualitas tanah yang relative murah adalah pemamfaatan sumber bahan organik, seperti pengembalian sisa tanaman. Selama ini upaya pemulihan dilakukan dengan menggunakan berbagai pembenah tanah organik berupa biochar

Biochar juga merupakan bahan organik yang memiliki sifat stabil dapat dijadikan pembenah tanah lahan kering. Pemilihan bahan baku biochar in didasarkan pada produksi sisa tanaman yang melimpah dan belulm termanfaatkan (Dermibas, 2004). Untuk saat ini produksi biomassa yang sangat melimpahdan kurang termanfaatkan ialah sekam padi. Sekam sebagai limbah penggilingan padi jumlahnya mencapai $20-23 \%$ dari gabah. Produksi Gabah Kering Giling (GKG) mencapai 71,29 juta ton, maka jumlah sekam yang dihasilkan di Indonesia sekitar 16,39 juta ton (BPS, 2013). Tidak hanya sekam padi melaiankan batang kirinyuh juga dapat dimanfaatkan sebagai bahan pembenah tanah ketika dijadikan biochar. Berdasarkan uraian diatas maka penelitian ini bertujuan untuk; mengetahui pengaruh pengaruh beberapa jenis biochar pada berbagai takaran terhadap pertumbuhan dan hasil tanaman kunyit di tanah entisol semiarid.

\section{Metode}

Penelitian ini telah dilaksanakan pada bulan Januari sampai dengan Mei 2020 yang berlokasi di Kebun Percobaan Fakultas Pertanian, Universitas Timor, Kelurahan Sasi, Kecamatan Kota, Kefamennu, TTU, NTT, Indonesia. Jenis tanahnya adalah tanah entisol. Penelitian ini menggunakan metode eksperimen dilapangan dengan rancangan acak kelompok (RAK) pola faktor tunggal. Faktor tunggal yaitu jenis biochar pada berbagai takaran dengan (K0) kontrol, (K1) biochar sekam padi 5 t/ha, (K2) biochar sekam padi 10 t/ha, (K3) biochar sekam padi $20 \mathrm{t} / \mathrm{ha}$, (K4) biochar kerinyuh $5 \mathrm{t} / \mathrm{ha}$, (K5) biochar kerinyuh 10 t/ha, dan (K6) biochar kerinyuh 20 t/ha sehingga terdapat 7 perlakuan yang diulang 5 kali maka diperoleh 35 perlakuan. Parameter pengamatan dalam penelitian ini adalah suhu tanah, kadar lengas tanah, berat volume tanah, tinggi tanaman, diameter batang semu, jumlah daun, pembentukan mata tunas rimpang, berat segar rimpang, berat kering tajuk, berat kering simplisia dan indeks panen. Data yang di peroleh merupakan data hasil pengamatan yang terdiri dari para meter pertumbuhan, parameter lingkungan, dan parameter hasil pada tanaman kunyit (Curcuma domestica Val.) data dianalisa menggunakan analysis of variance (Anova) dan diuji Duncan

\section{Hasil dan Pembahasan \\ 3.1 Hasil}

Suhu Tanah

Hasil sidik ragam anova menunjukkan tidak terjadi beda nyata antara aras perlakuan biochar dari awal pengamatan hingga akhir pengamatan terhadap parameter suhu tanah. Pada aras perlakuan kontrol memberikan nilai suhu tanah terendah pada pengamatan 126 hst dibandingkan aras perlakuan lainnya. Rata-rata suhu selama penelitian berkisar antara $31-35^{\circ} \mathrm{C}$ (Tabel 1)

Tabel 1. Suhu Tanah $\left({ }^{\circ} \mathrm{C}\right)$

\begin{tabular}{|c|c|c|c|c|}
\hline \multirow{2}{*}{\multicolumn{2}{|c|}{ Perlakuan }} & \multicolumn{3}{|c|}{ Rerata Suhu Tanah } \\
\hline & & $1 \mathrm{hst}$ & 63 hst & $126 \mathrm{hst}$ \\
\hline \multirow{4}{*}{ Biochar Sekam Padi } & $0 \mathrm{~T} / \mathrm{ha}$ & $34.00 \mathrm{a}$ & $32.00 \mathrm{a}$ & $31.00 \mathrm{a}$ \\
\hline & $5 \mathrm{~T} / \mathrm{ha}$ & $34.60 \mathrm{a}$ & $32.80 \mathrm{a}$ & $32.00 \mathrm{a}$ \\
\hline & $10 \mathrm{~T} / \mathrm{ha}$ & $33.00 \mathrm{a}$ & $33.20 \mathrm{a}$ & $35.00 \mathrm{a}$ \\
\hline & $20 \mathrm{~T} / \mathrm{ha}$ & $34.00 \mathrm{a}$ & $32.20 \mathrm{a}$ & $32.20 \mathrm{a}$ \\
\hline \multirow{4}{*}{$\begin{array}{l}\text { Biochar Batang } \\
\text { Kerinyu }\end{array}$} & $5 \mathrm{~T} / \mathrm{ha}$ & $32.00 \mathrm{a}$ & $31.80 \mathrm{a}$ & $34.40 \mathrm{a}$ \\
\hline & $10 \mathrm{~T} / \mathrm{ha}$ & $32.40 \mathrm{a}$ & $32.80 \mathrm{a}$ & $34.60 \mathrm{a}$ \\
\hline & $20 \mathrm{~T} / \mathrm{ha}$ & $33.20 \mathrm{a}$ & $31.60 \mathrm{a}$ & $31.20 \mathrm{a}$ \\
\hline & & tn & tn & tn \\
\hline
\end{tabular}

Keterangan: Nilai rata-rata pada kolom yang sama diikuti huruf yang sama menunjukkan tidak berbeda nyata pada menutur uji DMRT taraf 5\%, (tn) tidak berbeda nyata.

\section{Kadar Lengas Tanah}

Retensi air tanah atau kelengasan tanah adalah kemampuan tanah dalam menahan air di dalam pori-pori tanah, atau melepaskannya dari pori-pori tanah. Kondisi ini sangat tergantung pada tekstur, struktur dan pori-pori tanah. Hasil sidik ragam anova menununjukkan tiak terjadi beda nyata anatar aras perlakuan biochar dari awal pengamatan hingga akhir pengamatan terhadap parameter kadar lengas tanah. Pada aras pengamatan biochar sekam padi dengan takaran 20 t/ha pada pengamatan 63 hst mampu memberikan nilai kadar lengas tanah tertinggi dibanding aras perlakuan lainnya di waktu pengamatan yang berbeda (Tabel 2)

\section{Berat Volume Tanah}

Berat volume tanah merupakan perbandingan berat volume total termasuk pori tanah $\left(\mathrm{g} / \mathrm{cm}^{3}\right)$ tanah yang berbobot tinggi akan menyebabkan pergerakan akar sulit karena pori pada tanah penuh dengan material lainnya. Hasil sidik ragam anova menununjukkan tiak terjadi beda nyata anatar aras perlakuan biochar dari awal pengamatan hingga akhir pengamatan terhadap parameter berat volume tanah. Pada aras perlakuan biochar sekam padi $20 \mathrm{t} / \mathrm{ha}$ mampu memberikan nilai berat volume tanah tertinggi dibanding aras perlakuan lainnya di waktu pengamatan yang berbeda (Tabel 3) 
Tabel 2. Kadar Lengas Tanah (\%)

\begin{tabular}{ccccc}
\hline \multirow{2}{*}{ Perlakuan } & & \multicolumn{3}{c}{ Rerata Kadar Lengas Tanah } \\
& & $1 \mathrm{Hst}$ & $63 \mathrm{Hst}$ & $126 \mathrm{Hst}$ \\
\hline \multirow{3}{*}{ Biochar Sekam Padi } & $0 \mathrm{~T} / \mathrm{Ha}$ & $22.45 \mathrm{a}$ & $23.27 \mathrm{a}$ & $16.08 \mathrm{a}$ \\
& $5 \mathrm{~T} / \mathrm{Ha}$ & $21.29 \mathrm{a}$ & $22.14 \mathrm{a}$ & $17.39 \mathrm{a}$ \\
& $10 \mathrm{~T} / \mathrm{Ha}$ & $19.04 \mathrm{a}$ & $18.72 \mathrm{a}$ & $13.27 \mathrm{a}$ \\
& $20 \mathrm{~T} / \mathrm{Ha}$ & $22.18 \mathrm{a}$ & $23.51 \mathrm{a}$ & $18.24 \mathrm{a}$ \\
Biochar Batang Kerinyuh & $5 \mathrm{~T} / \mathrm{Ha}$ & $21.82 \mathrm{a}$ & $20.62 \mathrm{a}$ & $19.15 \mathrm{a}$ \\
& $10 \mathrm{~T} / \mathrm{Ha}$ & $22.49 \mathrm{a}$ & $21.01 \mathrm{a}$ & $20.78 \mathrm{a}$ \\
& $20 \mathrm{~T} / \mathrm{Ha}$ & $20.53 \mathrm{a}$ & $19.50 \mathrm{a}$ & $21.79 \mathrm{a}$ \\
\hline
\end{tabular}

Keterangan: Nilai rata-rata pada kolom yang sama diikuti huruf yang sama menunjukkan tidak berbeda nyata pada menutur uji DMRT taraf 5\%, (tn): Tidak berbeda nyata

Tabel 3. Berat Volume Tanah $(\mathrm{g} / \mathrm{cm} 3)$

\begin{tabular}{lcccc}
\hline \multirow{2}{*}{ Perlakuan } & & \multicolumn{3}{c}{ Rerata Berat Volume } \\
& & $1 \mathrm{hst}$ & $63 \mathrm{hst}$ & $126 \mathrm{hst}$ \\
\hline \multirow{3}{*}{ Biochar Sekam Padi } & $5 \mathrm{~T} / \mathrm{ha}$ & $3.07 \mathrm{a}$ & $3.27 \mathrm{a}$ & $2.07 \mathrm{a}$ \\
& $10 \mathrm{~T} / \mathrm{ha}$ & $2.81 \mathrm{a}$ & $3.36 \mathrm{a}$ & $3.11 \mathrm{a}$ \\
& $20 \mathrm{~T} / \mathrm{ha}$ & $4.04 \mathrm{a}$ & $3.22 \mathrm{a}$ & $3.06 \mathrm{a}$ \\
Biochar Batang Kerinyuh & $5 \mathrm{~T} / \mathrm{ha}$ & $3.79 \mathrm{a}$ & $3.63 \mathrm{a}$ & $2.89 \mathrm{a}$ \\
& $10 \mathrm{~T} / \mathrm{ha}$ & $2.91 \mathrm{a}$ & $3.50 \mathrm{a}$ & $3.06 \mathrm{a}$ \\
& $20 \mathrm{~T} / \mathrm{ha}$ & $2.96 \mathrm{a}$ & $3.49 \mathrm{a}$ & $3.00 \mathrm{a}$ \\
\hline
\end{tabular}

Keterangan: Nilai rata-rata pada kolom yang sama diikuti huruf yang sama menunjukkan tidak berbeda nyata pada menutur uji DMRT taraf $5 \%$, (tn): Tidak berbeda nyata

\section{Tinggi Tanaman}

Hasil sidik ragam anova menununjukkan tidak terjadi beda nyata antara aras perlakuan biochar dari awal pengamatan hingga akhir pengamatan terhadap parameter tinggi tanaman. Pada waktu pengamatan $21 \mathrm{hst}, 42 \mathrm{hst}$, dan 63 hst aras perlakuan biochar sekam padi dengan takaran 20t/ha memberikan nilai tertinggi. Sedangkan pada waktu pengamatan 84 hst dan 105 hst perlakuan biochar batang kerinyuh dengan takaran 20 t/ha memberikan nilai tinggi tanaman tertinggi (Tabel 4)

Tabel 4. Tinggi Tanaman $(\mathrm{cm})$

\begin{tabular}{|c|c|c|c|c|c|c|}
\hline \multirow{2}{*}{\multicolumn{2}{|c|}{ Perlakuan }} & \multicolumn{3}{|c|}{ Rerata Tinggi Tanaman } & \multirow[b]{2}{*}{84 hst } & \multirow[b]{2}{*}{$105 \mathrm{hst}$} \\
\hline & & $21 \mathrm{hst}$ & $42 \mathrm{hst}$ & $63 \mathrm{hst}$ & & \\
\hline \multirow{4}{*}{$\begin{array}{c}\text { Biochar Sekam } \\
\text { Padi }\end{array}$} & $0 \mathrm{~T} / \mathrm{ha}$ & $8.10 \mathrm{a}$ & $15.42 \mathrm{a}$ & $29.00 \mathrm{a}$ & $36.80 \mathrm{a}$ & $48.40 \mathrm{a}$ \\
\hline & $5 \mathrm{~T} / \mathrm{ha}$ & $7.80 \mathrm{a}$ & $15.10 \mathrm{a}$ & $33.20 \mathrm{a}$ & $41.40 \mathrm{a}$ & $53.60 \mathrm{a}$ \\
\hline & $10 \mathrm{~T} / \mathrm{ha}$ & $9.80 \mathrm{a}$ & $16.92 \mathrm{a}$ & $37.20 \mathrm{a}$ & $46.80 \mathrm{a}$ & $57.80 \mathrm{a}$ \\
\hline & $20 \mathrm{~T} / \mathrm{ha}$ & $16.80 \mathrm{a}$ & $21.32 \mathrm{a}$ & $39.60 \mathrm{a}$ & $48.40 \mathrm{a}$ & $60.00 \mathrm{a}$ \\
\hline \multirow{4}{*}{$\begin{array}{c}\text { Biochar Batang } \\
\text { Kerinyu }\end{array}$} & $5 \mathrm{~T} / \mathrm{ha}$ & $9.20 \mathrm{a}$ & $16.00 \mathrm{a}$ & $34.60 \mathrm{a}$ & $46.20 \mathrm{a}$ & $59.60 \mathrm{a}$ \\
\hline & $10 \mathrm{~T} / \mathrm{ha}$ & $9.72 \mathrm{a}$ & $14.34 \mathrm{a}$ & $37.40 \mathrm{a}$ & $50.60 \mathrm{a}$ & $63.60 \mathrm{a}$ \\
\hline & $20 \mathrm{~T} / \mathrm{ha}$ & $7.10 \mathrm{a}$ & $13.12 \mathrm{a}$ & $33.00 \mathrm{a}$ & $51.40 \mathrm{a}$ & $63.40 \mathrm{a}$ \\
\hline & & tn & tn & tn & tn & tn \\
\hline
\end{tabular}

Keterangan: Nilai rata-rata pada kolom yang sama diikuti huruf yang sama menunjukkan tidak berbeda nyata pada menutur uji DMRT taraf 5\%, (tn): Tidak berbeda nyata

\section{Diameter Batang Semu}

Hasil sidik ragam anova menununjukkan terjadi beda nyata antar aras perlakuan biochar sekam padi dengan biochar batang kerinyuh dari awal pengamatan hingga akhir pengamatan terhadap parameter diameter batang. Pada aras perlakuan biochar batang kerinyuh dengan takaran 10t/ha dan $20 \mathrm{t} / \mathrm{ha}$ memberikan nilai diameter batang tertinggi dibandingkan aras perlakuan lainnya dan diameter batang terendah terdapat pada aras perlakuan kontrol (Tabel 5)

\section{Tabel 5. Diameter Batang Semu (cm)}

\begin{tabular}{lcccccc}
\hline \multirow{2}{*}{ Perlakuan } & \multicolumn{5}{c}{ Rerata Diameteer batang } \\
\cline { 3 - 7 } & & $21 \mathrm{hst}$ & $42 \mathrm{hst}$ & $63 \mathrm{hst}$ & $84 \mathrm{hst}$ & $105 \mathrm{hst}$ \\
\hline \multirow{3}{*}{ Biochar Sekam } & $5 \mathrm{~T} / \mathrm{ha}$ & $0.18 \mathrm{~b}$ & $0.28 \mathrm{~b}$ & $0.38 \mathrm{~b}$ & $0.48 \mathrm{~b}$ & $0.52 \mathrm{~b}$ \\
Padi & $10 \mathrm{~T} / \mathrm{ha}$ & $0.38 \mathrm{ab}$ & $0.48 \mathrm{ab}$ & $0.58 \mathrm{ab}$ & $0.66 \mathrm{ab}$ & $0.70 \mathrm{ab}$ \\
& $20 \mathrm{~T} / \mathrm{ha}$ & $0.38 \mathrm{ab}$ & $0.48 \mathrm{ab}$ & $0.58 \mathrm{ab}$ & $0.68 \mathrm{ab}$ & $0.78 \mathrm{ab}$ \\
\multirow{2}{*}{ Biochar Batang } & $5 \mathrm{~T} / \mathrm{ha}$ & $0.50 \mathrm{a}$ & $0.60 \mathrm{a}$ & $0.70 \mathrm{a}$ & $0.80 \mathrm{a}$ & $0.88 \mathrm{a}$ \\
Kerinyu & $10 \mathrm{~T} / \mathrm{ha}$ & $0.48 \mathrm{a}$ & $0.58 \mathrm{a}$ & $0.68 \mathrm{a}$ & $0.78 \mathrm{a}$ & $0.90 \mathrm{a}$ \\
& $20 \mathrm{~T} / \mathrm{ha}$ & $0.50 \mathrm{a}$ & $0.60 \mathrm{a}$ & $0.70 \mathrm{a}$ & $0.80 \mathrm{a}$ & $0.90 \mathrm{a}$ \\
\hline
\end{tabular}

Keterangan: Nilai rata-rata pada kolom yang sama diikuti huruf yang sama menunjukkan tidak berbeda nyata pada menutur uji DMRT taraf $5 \%,(*)$ : Berbeda nyata.

\section{Jumlah Daun}

Hasil sidik ragam anova menunjukkan tidak terjadi beda nyata antara aras perlakuan biochar terhadap parameter jumlah daun pada waktu pengamatan 21, 42, dan 63 hst namun terjadi beda nyata pada waktu pengamatan 84 dan 105 hst. Pada aras perlakuan biochar sekam padi dengan takaran 10 t/ha memberikan nilai jumlah daun terbanyak yaitu 11.40 helai (Tabel 6)
Tabel 6. Jumlah Daun (helai)

\begin{tabular}{lcccccc}
\hline \multirow{2}{*}{ Perlakuan } & \multicolumn{5}{c}{ Rerata Jumlah Daun } \\
\cline { 3 - 7 } & & $21 \mathrm{hst}$ & $42 \mathrm{hst}$ & $63 \mathrm{hst}$ & $84 \mathrm{hst}$ & $105 \mathrm{hst}$ \\
\hline \multirow{4}{*}{ Biochar Sekam Padi } & $0.60 \mathrm{~T}$ & $2.80 \mathrm{a}$ & $5.60 \mathrm{a}$ & $7.80 \mathrm{ab}$ & $9.80 \mathrm{ab}$ \\
& $5 \mathrm{~T} / \mathrm{ha}$ & $0.40 \mathrm{a}$ & $3.20 \mathrm{a}$ & $5.00 \mathrm{a}$ & $7.00 \mathrm{ab}$ & $9.00 \mathrm{ab}$ \\
& $10 \mathrm{~T} / \mathrm{ha}$ & $1.00 \mathrm{a}$ & $3.00 \mathrm{a}$ & $7.40 \mathrm{a}$ & $9.40 \mathrm{a}$ & $11.40 \mathrm{a}$ \\
\multirow{2}{*}{ Biochar Batang } & $20 \mathrm{~T} / \mathrm{ha}$ & $1.60 \mathrm{a}$ & $3.60 \mathrm{a}$ & $6.40 \mathrm{a}$ & $8.60 \mathrm{ab}$ & $10.60 \mathrm{ab}$ \\
Kerinyu & $5 \mathrm{~T} / \mathrm{ha}$ & $0.80 \mathrm{a}$ & $3.40 \mathrm{a}$ & $6.40 \mathrm{a}$ & $8.40 \mathrm{ab}$ & $10.40 \mathrm{ab}$ \\
& $10 \mathrm{~T} / \mathrm{ha}$ & $0.80 \mathrm{a}$ & $3.40 \mathrm{a}$ & $7.00 \mathrm{a}$ & $9.00 \mathrm{ab}$ & $11.00 \mathrm{ab}$ \\
& $20 \mathrm{~T} / \mathrm{ha}$ & $0.60 \mathrm{a}$ & $3.00 \mathrm{a}$ & $4.60 \mathrm{a}$ & $6.40 \mathrm{~b}$ & $8.40 \mathrm{~b}$ \\
\hline
\end{tabular}

Keterangan: Nilai rata-rata pada kolom yang sama diikuti huruf yang sama menunjukkan tidak berbeda nyata pada menutur uji DMRT taraf 5\%, (tn) tidak berbeda nyata, (*) beda nyata

\section{Parameter Hasil}

Hasil sidik ragam anova menunjukan terjadi beda nyata antar aras perlakuan biochar terhadap parameter pembentukan mata tunas rimpang. Pada aras perlakuan biochar sekam padi dengan takaran $20 \mathrm{t} / \mathrm{ha}$ memberikan nilai pembentukan mata tunas rimpang (PMTR) tertinggi. Selanjutnya pada parameter berat segar rimpang (BSR) aras perlakuan biochar batang kerinyuh dengan takaran 5 t/ha dan tidak berbeda nyata dengan biochar sekam padi 20t/ha memberikan nilai berat segar rimpang terberat. Sedangkan pada parameter berat kering tajuk (BKT) hasil sidik ragam anova menunjukkan tidak terjadi beda nyata namun perlakuan biochar batang kerinyuh 20t/ha memberikan nilai berat kering tajuk (BKT)tertinggi. Pada parameter berat kering simplisia hasil sidik ragam anova menunjukkan terjadi beda nyata antar aras perlakuan biochar. Pada aras perlakuan biochar batang kerinyuh 20 t/ha memberikan nilai berat kering simplisia (BKS) tertinggi begitupun pada parameter indeks panen (IP) aras perlakuan biochar batang kerinyuh $20 \mathrm{t} / \mathrm{ha}$ kembali memberikan nilai tertinggi meskipun tidak berbeda nyata (Tabel 7)

Tabel 7. Parameter PMTR, BSR, BKT, BKS dan IP

\begin{tabular}{lcccccc}
\hline \multirow{2}{*}{ Perlakuan } & & \multicolumn{5}{c}{ Rerata Parameter Hasil } \\
\cline { 3 - 7 } & & PMTR & BSR & BKT & BKS & IP \\
\hline \multirow{4}{*}{ Biochar Sekam Padi } & $5 \mathrm{~T} / \mathrm{Ha}$ & $29.32 \mathrm{a}$ & $38.71 \mathrm{~b}$ & $1.02 \mathrm{a}$ & $6.06 \mathrm{~b}$ & $14.28 \mathrm{a}$ \\
& $10 \mathrm{~T} / \mathrm{Ha}$ & $45.83 \mathrm{a}$ & $50.46 \mathrm{~b}$ & $1.22 \mathrm{a}$ & $9.35 \mathrm{ab}$ & $5.25 \mathrm{a}$ \\
& $20 \mathrm{~T} / \mathrm{Ha}$ & $49.79 \mathrm{a}$ & $108.32 \mathrm{ab}$ & $1.32 \mathrm{a}$ & $12.59 \mathrm{ab}$ & $7.48 \mathrm{a}$ \\
\multirow{2}{*}{ Biochar Batang } & $5 \mathrm{~T} / \mathrm{Ha}$ & $52.38 \mathrm{a}$ & $125.06 \mathrm{a}$ & $1.96 \mathrm{a}$ & $21.50 \mathrm{a}$ & $5.36 \mathrm{a}$ \\
Kerinyu & $10 \mathrm{~T} / \mathrm{Ha}$ & $44.81 \mathrm{a}$ & $72.70 \mathrm{ab}$ & $1.41 \mathrm{a}$ & $11.77 \mathrm{ab}$ & $10.32 \mathrm{a}$ \\
& $20 \mathrm{~T} / \mathrm{Ha}$ & $26.82 \mathrm{a}$ & $78.09 \mathrm{ab}$ & $4.66 \mathrm{a}$ & $15.35 \mathrm{ab}$ & $15.60 \mathrm{a}$ \\
\hline & & tn & $*$ & tn & $*$ & tn \\
\hline
\end{tabular}

Keterangan: Nilai rata-rata pada kolom yang sama diikuti huruf yang sama menunjukkan tidak berbeda nyata pada menutur uji DMRT taraf 5\%, (tn) tidak berbeda nyata, (*) beda nyata.

\subsection{Pembahasan}

Hasil sidik ragam anova menunjukkan tidak terjadi beda nyata antara aras perlakuan biochar terhadap parameter pertumbuhan. Namun terjadi beda nyata pada perlakuan diameter batang disetiap waktu pengamatan dan parameter jumlah daun di waktu pengamatan 84 dan 105. Pada parameter tinggi tanaman aras perlakuan biochar batang kerinyuh 20 t/ha memberikan nilai tinggi tanaman tertinggi. Pada faktor jenis kompos biochar selama masa pertumbuhan tanaman jahe merah dapat menunjukan bahwa pemberian kompos biochar batang kirinyuh lebih tinggi selama masa pertumbuhan tanaman. Ini diakibatkan oleh perubahan komposisi dan aktivitas enzim di daerah sekitar perakaran yang meningkat dengan penambahan biochar.Menurut Graber et.al., (2010), kehadiran biochar dapat merangsang populasi rhizobakteria dan fungi yang menguntungkan bagi pertumbuhan tanaman. Ini diakibatkan oleh perubahan komposisi dan aktivitas enzim di daerah sekitar perakaran yang meningkat dengan penambahan biochar. Hal ini didukung dengan pernyataan (Rondon et al., 2007; Novak dkk., 2009; Baronti dkk. 2010; Nigussie dkk., 2012). Bahwa pemberian biochar secara tidak langsung akan berdampak positif terhadap pertumbuhan tanaman karena biochar berfungsi memperbaiki sifat fisik, kimia dan biologi tanah. Berkaitan tentang tanah dalam penelitian ini dilakukan beberapa unsur lingkungan yang sangat menentukan pertumbuhan serta hasil tanaaman kunyit. Hasil sidik ragam anova menunjukkan tidak terjadi beda nyata pada parameter lingkungan. Pada parameter lingkungan aras perlakuan biochar sekam padi dan biochar batang kerinyuh dengan takaran 10 dan 20 t/ha memberikan nilai tertinggi disetiap pengamatan. Pada parameter suhu tanah pada aras perlakuan kontrol memberikan nilai suhu tanah terendah pada pengamatan 126 hst dibandingkan aras perlakuan lainnya. Hal ini disebabkan karena dengan pemberian biochar kedalam tanah yang mengakibatkan suhu tanah munurun $27-30^{\circ} \mathrm{C}$ (Dariah et al., 2003).

Hasil sidik ragam anova menunjukkan tidak terjadi beda nyata antar aras perlakuan biochar namun terjadi beda nyata pada parameter berat segar rimpang dan berat kering simplisia. Pada parameter hasil aras perlakuan batang kerinyuh dengan takaran $5 \mathrm{t} / \mathrm{Ha}$ memberikan nilai tertinggi terhadap parameter pembentukan mata tunas rimpang, berat segar rimpang, dan berat kering simplisia hal ini dikarenakan pertumbuhan tanaman dilahan kering oleh 
aplikasi biochar disebabkan oleh peningkatan kandungan klofil hingga memacu laju fotosintesis, peningkatan konduktansi stomata, kandungan air relative, di daun dan efisiensi pemamfaatan air Pada parameter berat kering tajuk dan indeks panen aras perlakuan biochar batang kerinyuh dengan takaran $20 \mathrm{t} / \mathrm{ha}$ memberikan nilai tertinggi yaitu 4.66 gram dan indeks panen tertinggi yaitu $15.60 \%$. Pemberian kompos biochar arang sekam padi dan biochar batang kirinyu dapat meningkatkan pertumbuhan tanaman jahe tertinggi hal ini disebabkan karena biochar sekam padi memiliki kandungan c organic $>35 \%$ dan kandungan unsur hara makro seperti N, P, dan $\mathrm{K}$ yang cukup tinggi, (Nurida et al., 2012).

\section{Simpulan}

Berdasarkan Hasil penelitian menunjukkan bahwa perlakuan biochar sekam padi $10 \mathrm{t} / \mathrm{Ha}$ dan $20 \mathrm{t} / \mathrm{Ha}$ berpengaruh nyata dan memberikan nilai tertinggi tehadap parameter pertumbuhan yang meliputi panjang daun, jumlah daun serta parameter lingkungan yaitu berat volume tanah sedangkan perlakuan biochar batang kerinyuh $20 \mathrm{t} / \mathrm{Ha}$ memberikan nilai tertinggi terhadap parameter kadar lengas tanah dan tidak berbeda nyata. Pada parameter pertumbuhan 10 dan $20 \mathrm{t} / \mathrm{Ha}$ memberikan nilai tertinggi terhadap parameter tinggi tanaman dan diameter batang. Selanjutnya pada parameter hasil perlakuan biochar batang kerinyuh $5 \mathrm{t} / \mathrm{Ha}$ memberikan nilai tertinggi pada parameter pembentukan mata tunas rimpang, berat segar rimpang, dan berat kering simplisia. Sedangkan pada parameter berat kering tajuk dan indeks panen perlakuan biochar batang kerinyuh 20 t/Ha memberikan nilai tertinggi.

\section{Pustaka}

Anas, I., D. Utami, T. Yuliawati, T. Muluk 2003. Lobak (Raphinus spinosum) dan bayam (Amaranthus spp.) sebagai pengganti tanaman Cress (Lepidum sativum) dalam pengujian tingkat kematangan kompos. J. Penelitian Pertanian. 22 (1) : 34-40.

Badan Pusat Statistik (BPS). 2013. ProduktivitasTanaman Padi di Indonesia (Online) Available at http://www.bps.gp.id.

Baronti, S., G. Alberti, G. D. Vedove, F. D. Gennaro, G. Fellet, L. Genesio, F Miglietta, A. Peressotti, dan F. P. Vaccari. 2010. The Biochar Option To Improve Plant Yields: First Result From Some Field and Pot Experiments in Italy. Ital. J. Agron., 5:3 - 11

Berek, A.K. 2017. Teh Kompos dan Pemanfaatannya sebagai Sumber Hara danAgen Ketahanan Tanaman. Savana Cendana, 2(04): 68-70.

Dariah, A., N.L. Nurida and Sutono. 2013. The effect of biochar on soil quality and maize production in upland in dry climate region. In Proceeding 11th international Conference the East and Southeast Asia federation of Soil Science Societies. Bogor, Indonesia

Dermibas, A. 2004. Effects of temperatureand particle size on biochar yield from pyrolysis of agricultural residues. J. Of Analitical and Application Pyrolysis 72(2): 243-248.

Graber, E.R., Y.M. Harel, M. Kolton, E. Crtryn, A. Silber, D.R. David, L. Tsechansky, M. Borenshtein, and Y. Elad, 2010. Biochar Impact on Developmenr and Productivity of Pepper and Tomato grown in Fertigated Soilless Media. Plant Soil 337: 481-496.

Nigussie, A., E. Kissi, M. Misganaw, dan G. Ambaw. 2012. Effect Of Biochar Application on Soil Properties and Nutrient Uptake Of Lettuces (Lactuca sativa) Grown In Chromium Polluted Soils. AmericanEurasian J. Agric. \& Environ. Sci., 12:3: 369 - 376.

Novak, J.M., W.J. Busscher, D.L. Laird, M. Ahmedna, D.W. Watts, and M.A.S. Niandou. 2009a. Impact of biochar amendment on fertility of a southeastern coastal plain. Soil Science 174:105-111

Nurida., N.L., A. Rachman dan Sutono. 2012. Potensi pembenah tanah biochar dalam pemulihan sifat tanah terdegradasi dan peningkatan hasil jagung pada Typic Kanhapludults lampung. Jurnal Penelitian IlmuIlmu Kelaman: Buana Sains. Tribhuana Press. Vol 12:No. 1. Hal: 69-74

Rahardjo., M. Rostina. O. 2005. Budidaya tanaman kunyit Badan penelitian dan pengembangan pertanian. Balaipenelitian tanaman obat dan aromatika.

Rondon, M.A., J. Lehmann, J. Ramirez, dan M. Hurtado, 2007. Biological Nitrogen Fixation by Common Beans (Phaseolus vulgaris L.) Increases with Bio-char additions. Biology and Fertility Soils 43: 699-708.

Sumarni, N, Rosliani, R, Basuki, RS \& Hilman, Y 2012 a, 'Respons tanaman bawang merah terhadap pemupukan fosfat pada beberapa tingkat kesuburan lahan (Status P - Tanah)', Hort., vol. 22, no. 2, hlm. 1308 . 